\title{
Evaluation of Different Substrates for Production of Milky Mushroom (Calocybe indica P\&C) in Odisha
}

\author{
Niranjan Chinara $^{1 *}$ and Shyama Sundar Mahapatra ${ }^{2}$ \\ ${ }^{1}$ All India Coordinated Research Project on Mushroom, OUAT, \\ Bhubaneswar, Odisha-751003, India \\ ${ }^{2}$ Regional Research and Technology Transfer Station, Ranital, Bhadrak, \\ Odisha- 756111, India, India \\ *Corresponding author
}

\section{A B S T R A C T}

\section{Keywords}

Milky mushroom,

Sugarcane baggase and niger stick, Lignocellulosic

\section{Article Info}

Accepted:

21 May 2020

Available Online:

10 June 2020

\begin{abstract}
Milky mushroom (Calocybe indica $\mathrm{P} \& \mathrm{C}$ ) is an indigenous mushroom suitable for tropical region of the country which can be grown in different agro-wastes. To ascertain the efficacy of substrates, an experiment was conducted with different lignocellulosic substrates for production of milky mushroom. Ten different lignocellulosic substrates viz. paddy straw, maize stalk, maize cob, wheat straw, green gram stalk, groundnut shell, coir pith, mustard stalk, sugarcane baggase and niger stick were evaluated and data on days to spawn run, days to pin head formation, days to first harvest, number of mushrooms, yield per bag and biological efficiency as well morphological characteristics like pileus diameter, stipe length and stipe diameter were recorded from five randomly selected mushrooms of each treatment. Highest biological efficiency (BE) was recorded from wheat straw $(86.8 \%)$ with $1302 \mathrm{~g}$ mushroom /1500 g dry substrate followed by paddy straw $(74.2 \%)$. Early spawn run, pinhead initiation and $1^{\text {st }}$ harvest was observed in wheat straw $(17.5 \mathrm{~d}, 24.3 \mathrm{~d}$ and $35.9 \mathrm{~d})$ as compared to paddy straw. Delayed $1^{\text {st }}$ harvest was recorded in coir pith (51.1d) followed by groundnut shell (49.6 d). The morphology and number of mushroom harvested from wheat straw was maximum that directly influenced the yield per bag. Highest pileus diameter, stipe length and stipe diameter was observed in mushroom harvested from wheat straw $(116.0 \mathrm{~mm}, 175.2 \mathrm{~mm}, 73.7 \mathrm{~mm})$ which was statistically at par with that of paddy straw. But, paddy straw substrate can be recommended for production of milky mushroom instead of wheat straw because of its unavailability in the state of Odisha.
\end{abstract}

\section{Introduction}

Mushrooms are the fruiting body of macro fungus, may be epigeous or hypogeous and unable to synthesize its own food due to lack of chlorophyll but derive their food from complex organic materials found in dead or living tissues of plants and animals. Out of about 74,000 species of fungi, more than 3,000 are reported as edible mushrooms of 300 species belonging to 70 genera reported in India (Chadha and Shrma, 1995; Hawksworth, 2001). Among them, a total of 100 species mushrooms are grown 
experimentally where as 5-6 species have been cultivated in industrial scale. At present, about 100 countries including India producing more than 380 lakh tons of mushrooms annually which has increased from 49.09 lakh tons in the year, 1994. Among the leading countries, China is now contributing about 80 $\%$ of global mushroom production. Total mushroom production of India was 1.29 lakh tons in the year 2016 which has increased to 1.55 lakh tons in 2018. In the year 2016, button mushroom contributed $73 \%$ followed by oyster mushroom (16\%), milky mushroom (3\%) and other mushrooms $(8 \%)$. Total mushroom produced in India comprising of five different mushrooms such as button mushroom (Agaricus spp), oyster mushroom (Pleurotus spp), straw mushroom (Volvariella volvacea) milky mushroom (Calocybe indica) and shiitake (Lentinula edodes) that contributing less than one per cent of world's production.

Calocybe indica $\mathrm{P} \& \mathrm{C}$ is a tropical mushroom and was reported first time from West Bengal, India (Purkayastha, 1974). It is popularly known as milky mushroom or white summer mushroom because of its milky white colour. Its white attractive colour with excellent keeping quality, ability to grow on wide range of agricultural wastes, high conversion rate and above all, its suitability for value addition have made it popular among all the edible mushrooms in recent times. It grows well in higher range of temperature $\left(25^{\circ}-30^{\circ} \mathrm{C}\right)$ with more than $85 \%$ humidity. Besides paddy straw, it can be grown in different agrowastes viz. wheat straw, maize, sugarcane, niger, groundnut haulm, sugarcane bagasses etc. But, productivity of mushroom depends upon the substrates.

In this context, an experiment was conducted for evaluation of different lignocellulosic substrates for production of milky mushrooms.

\section{Materials and Methods}

\section{Collection and maintenance of test fungus}

The present investigation was carried out in the Centre of Tropical Mushroom Research and Training (CTMRT), Odisha University of Agriculture and Technology (OUAT), Bhubaneswar, Odisha, India. During survey the milky mushroom strain (OCI 04) was collected from Betnoti, Baripada, Odisha in rainy season. The collected mushroom cultured by transferring small pieces of tissue from the junction of the pileus and stipe to petriplates under aseptic condition over flame of spirit lamp and incubated at $30 \pm 2^{0} \mathrm{C}$. The pure culture of fungus was sub-cultured every two months interval, sent to Agri Genome Labs Pvt. Ltd., Kerala for microbial identification and confirmed as milky mushroom (Calocybe indica). The same culture of milky mushroom was preserved in PDA slants and used for various studies during the whole period of investigation.

\section{Preparation of Spawn}

Mother spawn was prepared from pure culture of milky mushroom. Basically, wheat grains were used as substrate for preparation of spawn. Clean, healthy and bold wheat grains were selected, washed and boiled in a container till they soften. Boiled grains were spread over clean polythene sheet in order to drain out excess water and air dried under shade. Powder of calcium carbonate @ $2 \%$ on dry weight basis of wheat grain was mixed thoroughly to absorb excess moisture as well as maintain proper $\mathrm{pH}$ of the grain. The boiled and treated grains were filled $3 / 4^{\text {th }}$ of $375 \mathrm{ml}$ capacity bottle, plugged with non absorbent cotton and sterilised in autoclave for 2 hours at 22 psi. The sterilised wheat bottles were inoculated with pure culture of milky mushroom and incubated for 15 days to get mother spawn. 


\section{Preparation of mushroom bags}

In order to evaluate the substrates, ten different lignocellulosic substrates viz. paddy straw, maize stalk, maize cob, wheat straw, green gram stalk, groundnut shell, coir pith, mustard stalk, sugarcane baggase and niger stick were collected, dried and chopped into $2-4 \mathrm{~cm}$ size.

The chopped substrates were soaked in clean water for six hours and excess water was drained. The soaked substrates were pasteurised by means of hot water and dried under shade to maintain substrate moisture about $50-55 \%$. About $1.5 \mathrm{~kg}$ substrate was filled in a polythene bag with $10 \%$ spawn applied in layer method. Each substrate was replicated thrice with five bags per replication. Then about 10-20 small holes were made in all side of the bag for exchange of gases. The prepared bags were then incubated in dark room at a temperature of $25-35^{\circ} \mathrm{C}$ for spawn run and after that the colonised bags were transferred to cropping room for application of casing soil. Casing material was prepared by mixing garden soil and 2 years old FYM in order to provide physical support as well as to maintain moisture.

All the prepared bags were subjected to the ambient condition during experiment. The experiment was conducted once in each year from 2014 to 2016 and the pooled data are given in results and discussion. Triplicates were maintained for each treatment in Randomized Block Design (RBD).

Data on days to spawn run, days to pin head formation, number of mushrooms, yield per bag and biological efficiency were recorded. Similarly, pileus diameter, stipe length and stipe diameter were recorded from five randomly selected mushrooms of each treatment.

\section{Biological efficiency}

The productivity of mushrooms from different substrates was presented in terms of Biological Efficiency (BE) and calculated using following formula.

$\mathrm{BE}(\%)=\frac{\begin{array}{c}\text { Fresh weight of } \\ \text { sporophores }\end{array}}{\text { Dry weight of substrate }} \times 100$

\section{Results and Discussion}

Milky mushroom (Calocybe indica $\mathrm{P} \& \mathrm{C}$ ) can grow on different ligno - cellulosic agrowastes but productivity depends upon type of wastes. Therefore, to ascertain the productivity, ten different wastes were collected and evaluated for three consecutive years. The pooled data of days to spawn run, days to pin head initiation, days to first harvest, biological efficiency, average number of fruit bodies per bag, yield $(\mathrm{g} / \mathrm{bag})$, pileus diameter $(\mathrm{mm})$, stipe length $(\mathrm{mm})$ and stipe diameter $(\mathrm{mm})$ are presented in the table 1 and 2 separately.

From the table 1, it was revealed that the days to spawn run in the substrate varied from 17.5 days to 27.9 days. Minimum days requirement for spawn run was 17.5 days in case of wheat straw substrate followed by paddy straw (20.2 days) and green gram husk (21.6 days). However, maize stalk, mustard stalk and niger stick were statistically at par with each other. But coir pith required maximum time for spawn run in the substrate and was 27.4 days. The same trend was observed in days to pin head initiation and days to first harvest. Early harvest of milky mushroom was recorded from wheat straw i.e 35.9 days. The range of mushroom yield varied from $540.0 \mathrm{~g}$ to $1302.0 \mathrm{~g}$ from $1.5 \mathrm{~kg}$ dry substrate. Among different substrates significantly highest yield (1302 g / bag) was 
obtained from wheat straw substrate with an average of 11.7 numbers of mushrooms followed by paddy straw (1113.3 g / bag) with 10.2 mushrooms. Though green gram husk was quicker than coir pith with respect to spawn run, pin head initiation and days to harvest but, expressed the lowest biological efficiency $(36.0 \%)$ followed by groundnut shell $(43.8 \%)$ and coir pith $(48.9 \%)$.

The efficacy of wheat straw as compared to other substrates presented in the table correlate with different workers (Kumar et al., 2014 and Suman et al., 2018). However, others reported paddy straw as the suitable substrate for production of milky mushroom in which wheat straw was not included in their experiments (Saranya et al., 2011; Karuppuraj et al., 2014; Singh et al., 2017). Our production of milky mushroom from maize cob, maize stalk and sugarcane bagasse was confirmed with Singh et al., 2017. The present result showed that higher BE in case of sugarcane bagasse $(59.1 \%)$ than coir pith (48.9\%) which was not supported by the findings of Amin et al., 2010 who reported paddy straw to be better. Wheat straw showed the best result with respect to days to spawn run, days to pin head initiation, days to first harvest, number of fruit bodies, biological efficiency and paddy straw was the superior substrate next to wheat straw. The present result was very close to the findings of Rawal et al., 2014.

Table.1 Evaluation of substrates for productivity of milky mushroom (Pooled)

\begin{tabular}{|c|c|c|c|c|c|c|c|}
\hline $\begin{array}{l}\text { Sl. } \\
\text { No. }\end{array}$ & Substrates & $\begin{array}{l}\text { Days to } \\
\text { spawn } \\
\text { run }\end{array}$ & $\begin{array}{c}\text { Days to } \\
\text { pin head } \\
\text { initiation }\end{array}$ & $\begin{array}{c}\text { Days to } \\
1^{\text {st }} \\
\text { harvest }\end{array}$ & BE (\%) & $\begin{array}{c}\text { Average } \\
\text { numbers } \\
\text { of fruit } \\
\text { bodies/ } \\
\text { bag }\end{array}$ & $\begin{array}{c}\text { Yield } \\
\text { (g) / } 1.5 \\
\text { kg dry } \\
\text { straw }\end{array}$ \\
\hline 1 & Paddy straw & 20.2 & 28.1 & 38.5 & 74.2 & 10.2 & $1113.3^{b}$ \\
\hline 2 & Maize stalk & 22.7 & 31.1 & 41.2 & 67.3 & 9.4 & $1010.0^{c}$ \\
\hline 3 & $\begin{array}{l}\text { Deseeded maize } \\
\text { cob }\end{array}$ & 25.7 & 34.7 & 46.8 & 58.9 & 8.2 & 883.3 \\
\hline 4 & Wheat straw & 17.5 & 24.3 & 35.9 & 86.8 & $11.7^{\mathrm{a}}$ & $1302.0^{\mathrm{a}}$ \\
\hline 5 & Green gram husk & 21.6 & 31.3 & 42.4 & 36.0 & 5.1 & 540.0 \\
\hline 6 & Groundnut shell & 26.5 & 38.6 & 49.6 & 43.8 & 6.1 & 656.7 \\
\hline 7 & Coir pith & 27.9 & 39.3 & 51.1 & 48.9 & 6.9 & 733.3 \\
\hline 8 & Mustard stalk & 23.2 & 32.5 & 41.7 & 64.0 & 8.8 & 960.0 \\
\hline 9 & $\begin{array}{l}\text { Sugarcane } \\
\text { bagasse }\end{array}$ & 23.5 & 34.0 & 44.7 & 59.1 & 8.1 & 886.7 \\
\hline \multirow[t]{3}{*}{10} & Niger stick & 23.3 & 32.3 & 42.5 & 65.6 & 9.2 & 983.3 \\
\hline & $\mathrm{SE}(\mathrm{m}) \pm$ & 0.23 & 0.28 & 0.35 & 1.77 & 0.33 & 26.48 \\
\hline & $\mathrm{CD}(0.05)$ & 0.65 & 0.81 & 0.99 & 5.01 & 0.93 & 75.08 \\
\hline
\end{tabular}


Table.2 Effect of substrates on morphology of milky mushroom (pooled)

\begin{tabular}{|l|l|c|c|c|}
\hline Sl. No. & Substrates & $\begin{array}{c}\text { Pileus size } \\
(\mathbf{m m})\end{array}$ & $\begin{array}{c}\text { Stipe length } \\
(\mathbf{m m})\end{array}$ & $\begin{array}{c}\text { Stipe } \\
\text { diameter }(\mathbf{m m})\end{array}$ \\
\hline $\mathbf{1}$ & Paddy straw & 111.8 & 171.7 & 72.3 \\
\hline $\mathbf{2}$ & Maize stalk & 108.1 & 158.8 & 67.7 \\
\hline $\mathbf{3}$ & Deseeded maize cob & 79.6 & 138.5 & 47.1 \\
\hline $\mathbf{4}$ & Wheat straw & 116.0 & 175.2 & 73.7 \\
\hline $\mathbf{5}$ & Green gram husk & 74.9 & 136.7 & 44.6 \\
\hline $\mathbf{6}$ & Groundnut shell & 71.0 & 131.9 & 53.3 \\
\hline $\mathbf{7}$ & Coir pith & 78.9 & 168.1 & 56.5 \\
\hline $\mathbf{8}$ & Mustard stalk & 94.5 & 165.2 & 63.7 \\
\hline $\mathbf{9}$ & Sugarcane bagasse & 88.4 & 167.2 & 47.2 \\
\hline $\mathbf{1 0}$ & Niger stick & 99.0 & 165.3 & 61.6 \\
\hline & SE(m) \pm & 2.89 & 2.82 & 1.83 \\
\hline & CD $(0.05)$ & 8.19 & 7.98 & 5.18 \\
\hline
\end{tabular}

Analysed data of pileus diameter (mm), stipe length $(\mathrm{mm})$ and stipe diameter $(\mathrm{mm})$ of milky mushroom presented in the table 2 was significantly different among the substrates evaluated. However, the morphology of mushroom has a great role in yield of mushroom per bag. The maximum pileus size $(116.0 \mathrm{~mm})$ was observed in the mushroom harvested from wheat straw which was statistically at par with that of paddy straw $(111.8 \mathrm{~mm})$ and maize stalk $(108.1 \mathrm{~mm})$. Similarly, mushroom harvested from niger stick $(99.0 \mathrm{~mm})$ and mustard stalk $(94.5 \mathrm{~mm})$ were statistically at par on the basis of pileus diameter. The lowest pileus diameter 71.0 $\mathrm{mm}$ was recorded in the mushroom harvested from groundnut shell which was at par with the mushroom from green gram husk (74.9 $\mathrm{mm})$ and coir pith $(78.9 \mathrm{~mm})$. It was also observed that the stipe length and stipe diameter of mushrooms harvested from wheat straw $(175.2 \mathrm{~mm}$ and $73.7 \mathrm{~mm})$ and paddy straw substrates $(171.7 \mathrm{~mm}$ and $72.3 \mathrm{~mm}$ ) were statistically similar. The stipe length of mushrooms harvested from coir pith, sugarcane bagasse, niger stick and mustard stalk were statistically at par with that of each other. Lowest stipe length was recorded 131.9 $\mathrm{mm}$ from mushroom grown on groundnut shell. Stipe diameter of mushroom from maize stalk and mustard stalk were statistically similar. Poor morphological characters were observed in mushroom from green gram husk and groundnut shell.

The morphology and number of mushroom harvested from wheat straw was maximum that directly influenced the yield per bag. Though morphology of mushroom from paddy straw was statistically at par with that of wheat straw, significant difference in number of mushrooms resulted significant difference with respect to yield in case of wheat straw. Lowest yield of mushroom from green gram husk was due to poor morphology as well as less number of mushrooms. Milky mushroom has the ability to degrade wide range of ligno cellulosic substances with a 
$\mathrm{C}: \mathrm{N}$ ratio of 40 to 60 . Perhaps, inferior quality and number of mushroom from green gram husk was due to less $\mathrm{C}: \mathrm{N}$ ratio (19.5) as compared to paddy straw (61.5) (Surekha, 2007).

Hence, from the above experiment, conclusion may be drawn to use the substrates of $\mathrm{C}: \mathrm{N}$ ratio more than 40 for cultivation of milky mushroom. Though wheat straw produced maxium mushroom, paddy straw substrate can be recommended instead of wheat straw because of its cheap availability in abundance in the state of Odisha.

\section{References}

Amin, R., Khair, A., Alam, N. and Lee, T. S. 2010. Effect of different substrates and casing materials on the growth and yield of Calocybe indica, Mycobiology, 38 (2): 97-101.

Chadhha, K.L. and Sharma, S. R. 1995. Mushroom research in India - history, infrastructure and achievements. In Advances in Horticulture, Vol.13. Mushroom. (K.L. Chadhha and S.R. Sharma, eds.), MPH, New Delhi, pp. 133.

Hawksworth, D. L. 2001. The magnitude of fungal diversity: the 1.5 million species estimate revisited, Mycological Research, 105:1422-1432.

Karuppuraj, V., Sekarenthiran, S.C. and Perumal, K. 2014. Yield improvement of Calocybe indica fruiting bodies (milky mushroom) from locally available unexplored lignocellulosic substrates, International Journal of
Scientific Research, 8(3):490-493.

Kumar, G.V., John, P. and Ganesh, K. 2014. Selection of different substrates for cultivation of milky mushroom (Calocybe indica $\mathrm{P} \& \mathrm{C}$ ), Indian Journal of Traditional Knowledge, 13(2):434436.

Purkayastha, R. P. and Chandra, A. 1974. New species of edible mushroom from India. Trans. Br. Mycol. Soc. 62: 415418.

Rawal, P. and Doshi, A. 2014. Evaluation of Substrates for Organic Cultivation of Milky Mushroom (Calocybe indica) strain APK-2, Periodic Research, 2(4): 28-30.

Saranya, V., Madhanraj, P. and Panneerselvam, A. 2011. Cultivation, composting, biochemical and molecular characterization of Calocybe indica (C and A). Asian. J. Pharm. Res. 3: 55-57.

Singh, V., Kumar P., Kumar, S. and Kumar, K. 2017. Yield performance of collected wild milky mushroom (Calocybe sp.), Plant Archives, 17(1): 181-186.

Suman, S.K., Kumar, M. and Dayaram. 2018. Evaluation of substrate on production of Calocybe indica (Milky white mushroom) under Bihar condition, International Journal of Current Microbiology and Applied Sciences, 7: 3694-3699.

Surekha, K. 2007. Nitrogen-release pattern from organic sources of different $\mathrm{C}$ : $\mathrm{N}$ ratios and lignin content and their contribution to irrigated rice (Oryza sativa), Indian Journal of Agronomy. 52: 220-224.

\section{How to cite this article:}

Niranjan Chinara and Shyama Sundar Mahapatra. 2020. Evaluation of Different Substrates for Production of Milky Mushroom (Calocybe indica P\&C) in Odisha. Int.J.Curr.Microbiol.App.Sci. 9(06): 3195-3200. doi: https://doi.org/10.20546/ijcmas.2020.906.382 